\title{
Selective Loss of Calcium Permeability on
}

\section{Maturation of Reticulocytes}

\author{
James S. Wiley and Calvin C. Shaller \\ From the Hematology-Oncology Section, Department of Medicine, Hospital of the University of \\ Pennsylvania, Philadelphia, Pennsylvania 19104
}

\begin{abstract}
A B S T RACT Calcium and sodium permeability of human reticulocytes have been studied and compared to mature erythrocytes. Mature erythrocytes had extremely low $\mathrm{Ca}^{2+}$ permeability which was less than $0.1 \%$ of values published for squid axon or HeLa cells. Calcium entry was markedly increased in reticulocyte-rich suspensions and the uptake was linearly related to the percentage of reticulocytes present. The data suggest that reticulocytes are 43-fold more permeable to $\mathrm{Ca}^{2+}$ than mature cells although their $\mathrm{Ca}^{2+}$ concentration is not increased. Sodium influx into reticulocyte-rich suspensions was also increased in direct proportion to the percent of reticulocytes present. Reticulocytes are sixfold more permeable to $\mathrm{Na}^{+}$than mature cells so the ratio of $\mathrm{Ca}^{2+}: \mathrm{Na}^{+}$ permeability falls by sevenfold as the reticulocyte changes to an erythrocyte. $\left[{ }^{3} \mathrm{H}\right]$ Ouabain binding was increased in reticulocyte-rich cell suspensions and the correlation suggested a value of about 4,000 sites per reticulocyte compared with $362 \pm 69$ per mature cell. Maturation of the human reticulocyte produces disproportionate changes in cation permeability and in particular a selective loss of $\mathrm{Ca}^{2+}$ permeability.
\end{abstract}

\section{INTRODUCTION}

Reticulocytes lose their ribosomes within $36 \mathrm{~h}$ after entering the peripheral blood, although this maturation time may be almost doubled in conditions of erythropoietic stress $(1,2)$. During the maturation process, reticulocyte volume decreases by $20-30 \%$ and several studies have shown that cytoplasmic hemoglobin and membrane lipids are decreased in the same

This work has appeared in preliminary form in 1974. Fed. Proc. 33: 266.

Dr. Wiley's present address is the Department of Medicine, Austin Hospital, Melbourne 3084, Australia.

Received for publication 22 November 1976 and in revised form 22 February 1977. proportion $(3,4)$. The two major lipids of the membrane, phospholipid and cholesterol, are both lost in parallel while changes in osmotic fragility confirm that membrane area is reduced (3). Major alterations in membrane transport occur during this maturation process. Reticulocytes possess a $\mathrm{Na}^{+}$-dependent transport system for alanine and $\alpha$-aminoisobutyric acid which disappears on cell maturation (5). Active transport of $\mathrm{Na}^{+}$is also lower in mature erythrocytes compared with reticulocyte-rich populations (6), although cation fluxes have not been correlated with reticulocyte numbers. In this study the fluxes of $\mathrm{Ca}^{2+}$ and $\mathrm{Na}^{+}$as well as the binding of $\left[{ }^{3} \mathrm{H}\right]$ ouabain have been measured in reticulocyte-rich erythrocytes. Results show a major reduction in $\mathrm{Ca}^{2+}$ permeability on maturation of reticulocytes which is almost an order of magnitude greater than the $\mathrm{Na}^{+}$permeability changes.

\section{METHODS}

Materials. $\mathrm{NaCl}, \mathrm{KCl}$, sodium EGTA, ${ }^{1} \mathrm{SrCl}_{2}$ were Analar grade from Fisher Scientific Co., Pittsburgh, Pa.; $\mathrm{LiCl}$ was from $K$ and $K$ Laboratories, Inc., Plainview, $N$. Y.; inosine, hexokinase, and glucose-6-phosphate dehydrogenase were from Boehringer, Mannheim, W. Germany; iodoacetic acid and sodium iodoacetamide were from Eastman Kodak Co., Rochester, N. Y.; ATP, NADP ${ }^{+}$, and Tris- $\mathrm{HCl}$ were from Sigma Chemical Co., St. Louis, Mo.; and ${ }^{45} \mathrm{CaCl}_{2}$ and ${ }^{22} \mathrm{NaCl}$ were from New England Nuclear, Boston, Mass. $\left[{ }^{3} \mathrm{H}\right]-$ Ouabain, $5 \mathrm{Ci} / \mathrm{mM}$ ethanol-benzene solution, New England Nuclear lot no. 184-196, was evaporated to dryness under a stream of nitrogen and redissolved in 20-fold excess of unlabeled ouabain to give a stock solution of $10 \mu \mathrm{M}$ ouabain in water of activity $12.5 \mu \mathrm{Ci} / \mathrm{ml}$. The exact concentration of ouabain was confirmed by spectrophotometric analysis with a molar extinction coefficient of $1.54 \times 10^{4}$ at the absorption peak of $220 \mathrm{~nm}$. (7). This stock solution was stable at $4^{\circ} \mathrm{C}$ for several months. Silica crucibles (high-form, $5 \mathrm{ml}$ capacity) were from Thermal American

${ }^{1}$ Abbreviations used in this paper: EGTA, ethylene glycolbis( $\beta$-aminoethyl ether $) N, N, N^{\prime}, N^{\prime}$-tetraacetate. 
Fused Quartz. Co., Montville, N. J.; standard solutions of $\mathrm{Ca}^{2+}(5-50 \mu \mathrm{M})$ were prepared by dilution of commercial $1,000 \mathrm{ppm} \mathrm{Ca}\left(\mathrm{NO}_{3}\right)_{2}$ (i.e., $25 \mathrm{mM}$ ) from Fisher Scientific Co. in a solution of $0.1 \mathrm{~N} \mathrm{HCl}$ plus $10 \mathrm{mM} \mathrm{SrCl}_{2}$.

High-reticulocyte blood donors. Patients were selected with peripheral blood reticulocytosis of $2.0-25 \%$ resulting from chronic autoimmune hemolytic anemia, pyruvate kinase deficiency hemolytic anemia, chronic gastrointestinal blood loss, or during hematinic therapy of a deficiency anemia. Patients with renal disease were excluded because of the inhibitory effects of uremic toxins on cation transport in the erythrocyte (8). Likewise, patients with liver disease, untreated megaloblastic anemia, or alcoholism were excluded because of their increased erythrocyte size and surface area (9). Sodium and $\mathrm{Ca}^{2+}$ influx were studied simultaneously in 8 of the 20 patients with reticulocytosis while 12 patients were studied with only one flux measurement.

Preparation of erythrocytes. Venous blood was collected into heparin and erythrocytes were separated from leukocytes by thrice washing at $4^{\circ} \mathrm{C}$ in a medium of composition 145 $\mathrm{mM} \mathrm{NaCl}, 5 \mathrm{mM} \mathrm{KCl}$, plus $20 \mathrm{mM}$ imidazole $\mathrm{Cl}, \mathrm{pH}$ 7.5. Care was taken to remove all buffy coat since both leukocytes and platelets contain large amounts of calcium. This basic medium was used for all incubations since the imidazole buffer does not associate with added $\mathrm{Ca}^{2+}$ ions.

Reticulocyte enumeration. During washing of erythrocytes and removal of buffy coat up to one-fourth of the reticulocytes may be lost. Therefore, the percentage of reticulocytes was always measured after washing. One drop of washed erythrocytes was mixed with three drops of autologous plasma and stained for $15 \mathrm{~min}$ with an equal volume of freshly-filtered $1.0 \%$ new methylene blue (10). The number of reticulocytes in 1,000 erythrocytes was counted.

Calcium influx. Washed erythrocytes were depleted of ATP by preincubation for $90 \mathrm{~min}$ in medium plus $1 \mathrm{mM}$ iodoacetate and $10 \mathrm{mM}$ inosine (11). The erythrocytes were then washed twice and added to prewarmed media of composition $145 \mathrm{mM} \mathrm{NaCl}, 5 \mathrm{mM} \mathrm{KCl}, 20 \mathrm{mM}$ imidazole $\mathrm{Cl}$, pH 7.5, plus $1.5 \mathrm{mM}^{45} \mathrm{CaCl}_{2}(1 \mu \mathrm{Ci} / \mathrm{ml})$. Samples were taken after $15 \mathrm{~min}$ and after $1,2,3$, and $4 \mathrm{~h}$, and washed four times in cold $150 \mathrm{mM} \mathrm{NaCl}$ plus $1 \mathrm{mM} \mathrm{Na}$ EGTA. Each cell pellet was hemolyzed in $0.01 \mathrm{~N} \mathrm{NH}_{4} \mathrm{OH}$, and part of the hemolysate was deproteinized with $6 \%$ ( $\mathrm{wt} / \mathrm{vol}$ ) perchloric acid plus $1 \mathrm{mM}$ Na EGTA and ${ }^{45} \mathrm{Ca}^{2+}$ in the supernate was measured by liquid scintillation counting. To convert the uptake of radioactive calcium from nanomoles per micromole $\mathrm{Hb}$ into nanomoles per milliliter cells, the mean corpuscular hemoglobin concentration was measured in each experiment both for the abnormal and normal cells. $\mathrm{Na}^{+}$ influx was measured in cells depleted of ATP by the above procedure to find if the iodoacetate treatment had induced a generalized permeability increase. No increase in $\mathrm{Na}^{+}$influx was found.

Total cell calcium concentration. Calcium was measured by atomic absorption spectroscopy of a dry ashed sample of erythrocytes. Erythrocytes, which had been washed free of buffy coat were further washed four times at $4^{\circ} \mathrm{C}$ in 150 $\mathrm{mM} \mathrm{NaCl}$ or $150 \mathrm{mM} \mathrm{LiCl}$ either with or without $1 \mathrm{mM}$ Na EGTA. The final pellet of washed cells was hemolyzed with $6 \mathrm{ml}$ of $0.01 \mathrm{~N} \mathrm{NH}_{4} \mathrm{OH}$ (verified $\mathrm{Ca}^{2+}$-free), and $5 \mathrm{ml}$ of the hemolysate was added to a silica crucible, slowly evaporated to dryness under an infrared lamp, and combusted at $500^{\circ} \mathrm{C}$ overnight in a muffle furnace. It was important that the sample was completely dry before combustion, since any trace of water led to uncontrollable bubbling when the sample was heated toward $500^{\circ} \mathrm{C}$. The residue in each crucible was extracted with dilute acid by adding $3 \mathrm{ml}$ of $0.1 \mathrm{~N} \mathrm{HCl}$ plus $10 \mathrm{mM} \mathrm{SrCl}_{2}$ to the crucible and shaking for $2 \mathrm{~h}$ at room temperature. The contents of the crucible were decanted into polypropylene tubes, and the iron oxide was allowed to settle. Calcium in the supernate was analyzed on a Varian Techtron 1200 Atomic Absorption Spectrophotometer (Varian Associates, Walnut Creek, Calif. at $422.6 \mathrm{~nm}$ with acetylene fuel plus compressed air. $\mathrm{Ca}^{2+}$ contaminant in $\mathrm{HCl}-\mathrm{SrCl}_{2}$ solution (solvent blank was $2 \mu \mathrm{M}$. A $1-\mathrm{ml}$ aliquot of the hemolysate was taken for measurement of hemoglobin concentration, so that the $\mathrm{Ca}^{2+}$ present in each crucible could be expressed as nanomoles per milliliter of cells.

Precautions to exclude calcium contamination. Isotomic $\mathrm{NaCl}$ and $\mathrm{LiCl}$ contain $1-4 \mu \mathrm{M} \mathrm{Ca}{ }^{2+}$ contaminant which was removed by filtering these solutions through a $8 \times 1.5$. $\mathrm{cm}$ column of Chelex-100 ion-exchange resin (Bio-Rad Laboratories, Richmond, Calif.). These solutions and others used in $\mathrm{Ca}^{2+}$ measurements were stored in polypropylene bottles since both glass and some polystyrene and polyethylene containers contribute small and variable amounts of $\mathrm{Ca}^{2+}$ to a solution. When Pyrex glassware was used, it was acid washed and kept immersed in deionized water until immediately before use, when it was again rinsed in deionized water. All crucibles had close-fitting lids, and after combustion the lids were dusted free of refractory brick dust before opening. Recovery studies of $\mathrm{Ca}^{2+}$ added to crucibles and dry ashed at $500^{\circ} \mathrm{C}$ established that no significant amounts of $\mathrm{Ca}^{2+}$ were retained by the silica crucibles. ${ }^{45} \mathrm{CaCl}_{2}(1.25,2.5,3.75,5$, and $74 \mathrm{nmol})$ was added to crucibles, $5 \mathrm{ml}$ of an erythrocyte hemolysate was added and the contents were dry ashed and extracted in dilute acid as above. The recovery of ${ }^{45} \mathrm{Ca}$ was estimated by liquid scintillation counting and was $81,85,86,98$, and $101 \%$, respectively, for each of the above amounts of added $\mathrm{Ca}^{2+}$

Sodium influx. This was measured from the uptake of radioactivity by cells incubated 10 and $20 \mathrm{~min}$ in media containing ${ }^{22} \mathrm{NaCl}$ as described by Wiley and Cooper (12). Media always contained glucose $(10 \mathrm{mM})$ plus ouabain $(50 \mu \mathrm{M})$.

ATP estimation. The cell suspension was deproteinized with $2 \mathrm{vol}$ of $0.6 \mathrm{~N}$-perchloric acid, centrifuged at $0^{\circ} \mathrm{C}$, and the supernate adjusted to $\mathrm{pH}$ 6-7 with $\mathrm{K}_{2} \mathrm{CO}_{3}$. ATP in the neutralized extract was estimated spectrophotometrically by measuring the reduction of $\mathrm{NADP}^{+}$by a coupled hexokinase-glucose-6-phosphate dehydrogenase reaction.

Creatine. This was measured in a neutralized perchloric acid extract of washed cells (13).

$\left[{ }^{3} \mathrm{H}\right]$ Ouabain binding to erythrocytes. Binding of ouabain was measured essentially as described by Hoffman (14) and Wiley et al. (15). Washed erythrocytes were incubated with $20 \mathrm{nM}\left[{ }^{3} \mathrm{H}\right]$ ouabain for 30 or $60 \mathrm{~min}$ after which cells were washed and $0.5-\mathrm{ml}$ portions of packed cells were added to $15 \mathrm{ml}$ Aquafluor (New England Nuclear) and counted after storage for $72 \mathrm{~h}$ in the dark. Another portion was taken for erythrocyte enumeration with the Coulter model ZB electronic particle counter (Coulter Electronics Inc., Hialeah, Fla.). Potassium influx was also measured to assess the fractional inhibition of the cation pump. ${ }^{42} \mathrm{KC}$. was added to the basic incubation medium to give a fina $\mathrm{K}^{+}$concentration of $5.6-7.2 \mathrm{mM}$ and influx measured over : 1-h incubation. The total number of ouabain-binding sites per cell was equated to the number of $\left[{ }^{3} \mathrm{H}\right]$ ouabain moie cules bound per cell when there was $100 \%$ inhibition of active $\mathrm{K}^{+}$influx.

Statistics. Mean values \pm 1 SD are shown unless otherwise noted. Regression lines and correlation coefficients were calculated by the method of least squares and differences between sample means analyzed by a $t$ test 
TABLE I

Calcium Concentration of Normal and Reticulocyte-Rich Erythrocytes

\begin{tabular}{lccccc}
\hline \multicolumn{1}{c}{ Diagnosis } & Reticulocytes & Washing medium & Mean calcium & SE & Range \\
\hline & $\%$ & & $n$ mol/ml cells & \\
Normals & $<1.0$ & $\mathrm{NaCl}$ & 5.7 & 0.8 & $3.6-7.4$ \\
Normals & $<1.0$ & $\mathrm{NaCl}+$ EGTA & 6.5 & 1.4 & $3.1-11.2$ \\
Normals & $<1.0$ & $\mathrm{LiCl}$ & 5.2 & 1.1 & $2.1-8.9$ \\
Normals & $<1.0$ & $\mathrm{LiCl}+$ EGTA & 6.3 & 0.6 & $5.0-8.3$ \\
G. I. blood loss & 11.4 & $\mathrm{NaCl}+$ EGTA & 3.7 & 0.6 & $2.7-5.7$ \\
Folate deficiency on therapy & 5.6 & $\mathrm{NaCl}+$ EGTA & 2.7 & 0.2 & $2.3-3.2$ \\
Autoimmune hemolytic anemia & 24 & $\mathrm{NaCl}+$ EGTA & 9.2 & 0.7 & $8.4-10.1$ \\
Autoimmune hemolytic anemia & 25 & $\mathrm{NaCl}+$ EGTA & 9.3 & 0.2 & $9.0-9.6$ \\
\hline
\end{tabular}

Normal group was three males and three females and the results with different washing media were always obtained with paired observations on the same cells on the same day. Measurements on the four patients with elevated reticulocytes were obtained from quadruplicate samples.

\section{RESULTS}

Erythrocyte calcium concentrations. The mean calcium content of erythrocytes from six normal donors was $5.9 \pm 1.8 \mathrm{nmol} / \mathrm{ml}$ cells after four washes in a verified $\mathrm{Ca}^{2+}$-free medium. Identical values were obtained whether the medium was isotonic $\mathrm{NaCl}$ or $\mathrm{LiCl}$ or whether the chelating agent, EGTA, was present or absent (Table I). The range of values obtained for replicate determinations on one individual is shown in Table I and usually fell within a twoor threefold range. The calcium content of erythrocytes from patients with a reticulocytosis $(5.6-25 \%)$ did not differ significantly from normal (Table I)

Calcium exchangeability. Erythrocyte $\mathrm{Ca}^{2+}$ exchanged with isotopic $\mathrm{Ca}^{2+}$ added to a physiological medium in which the cells were incubated at $37^{\circ} \mathrm{C}$. This exchange was complete by $5 \mathrm{~min}$ since the uptake of isotopic $\mathrm{Ca}^{2+}$ was the same in samples taken at 5, 10, 15 and $60 \mathrm{~min}$. Concurrent measurements of ${ }^{45} \mathrm{Ca}^{2+}$ uptake by liquid scintillation counting plus total cell $\mathrm{Ca}^{2+}$ concentration by atomic absorption showed that isotopic $\mathrm{Ca}^{2+}$ exchanged with only a fraction of total cell $\mathrm{Ca}^{2+}$. Two normals exchanged 15 and $40 \%$ of their total $\mathrm{Ca}^{2+}$, while the patient with $25 \%$ reticulocytes showed an $88 \%$ exchange. This greater exchangeability of reticulocyte $\mathrm{Ca}^{2+}$ was studied by measurements of unidirectional $\mathrm{Ca}^{2+}$ influx.

Calcium influx into normal erythrocytes. Unidirectional ${ }^{45} \mathrm{Ca}$ influx was studied in erythrocytes depleted of ATP to inhibit the outward pumping of $\mathrm{Ca}^{2+}$ ions (11). To deplete the ATP the washed erythrocytes were preincubated with $10 \mathrm{mM}$ inosine plus either $1 \mathrm{mM}$ iodoacetate or $5 \mathrm{mM}$ iodoacetamide. These inhibitors were equally effective in combination with inosine since ATP fell from $1.2 \mu \mathrm{mol} / \mathrm{ml}$ cells initially to less than $0.1 \mu \mathrm{mol} / \mathrm{ml}$ cells after $90 \mathrm{~min}$ (Fig. 1A).
Cells were again washed and incubated without inhibitors in media containing $1.5 \mathrm{mM}{ }^{45} \mathrm{Ca}^{2+}$ ion. A rapid initial uptake of isotopic $\mathrm{Ca}^{2+}$ occurred within 15 min followed by a slower uptake which was linear between $15 \mathrm{~min}$ and $4 \mathrm{~h}$ (Fig. 1B). In cells depleted by inosine plus iodoacetate the initial uptake was $2.3 \mathrm{nmol}$ $\mathrm{Ca}^{2+} / \mathrm{ml}$ cells and the linear phase averaged 0.8 $\mathrm{nmol} \mathrm{Ca}{ }^{2+} / \mathrm{ml}$ cells every hour to reach $5.4 \pm 1.5 \mathrm{nmol}$ $\mathrm{Ca}^{2+} / \mathrm{ml}$ cells after a 4 -h incubation. Calcium uptake by cells depleted of ATP by incubation with inosine plus iodoacetamide was not significantly different to the values above (Fig. 1B). Analysis of total $\mathrm{Ca}^{2+}$ in one experiment confirmed a net increase in this cation.

Calcium influx into reticulocytes. Calcium uptake is increased into erythrocytes from patients with a reticulocytosis. Cell suspensions with reticulocytes of 5.0 or $11.4 \%$ allowed approximately 6 - or 10 -fold greater $\mathrm{Ca}^{2+}$ uptake, respectively (Fig. 2). Similar uptakes were obtained for the same cells depleted of ATP by three different combinations of inhibitors: inosine plus iodoacetate, inosine plus iodoacetate plus cyanide, or inosine plus iodoacetamide. The combination of inosine plus iodoacetate was chosen to deplete cell ATP for all subsequent studies. The greater $\mathrm{Ca}^{2+}$ uptake by reticulocytes was confirmed with blood from a normal donor. The erythrocytes were washed free of buffy coat and fractionated by centrifugation into reticulocyte-rich and reticulocyte-poor fractions (16). Table II shows that the top fraction with $2.4 \%$ reticulocytes showed a twofold greater $\mathrm{Ca}^{2+}$ uptake than the reticulocyte-poor fractions.

Comparison of calcium and sodium influx. The large influx of $\mathrm{Ca}^{2+}$ into ATP-depleted reticulocytes suggests that the reticulocyte membrane is very permeable to this cation. Sodium influx was also measured in reticulocyte-rich cells for comparison with the $\mathrm{Ca}^{2+}$ fluxes. Fig. 3 shows that $\mathrm{Na}^{+}$influx was increased 

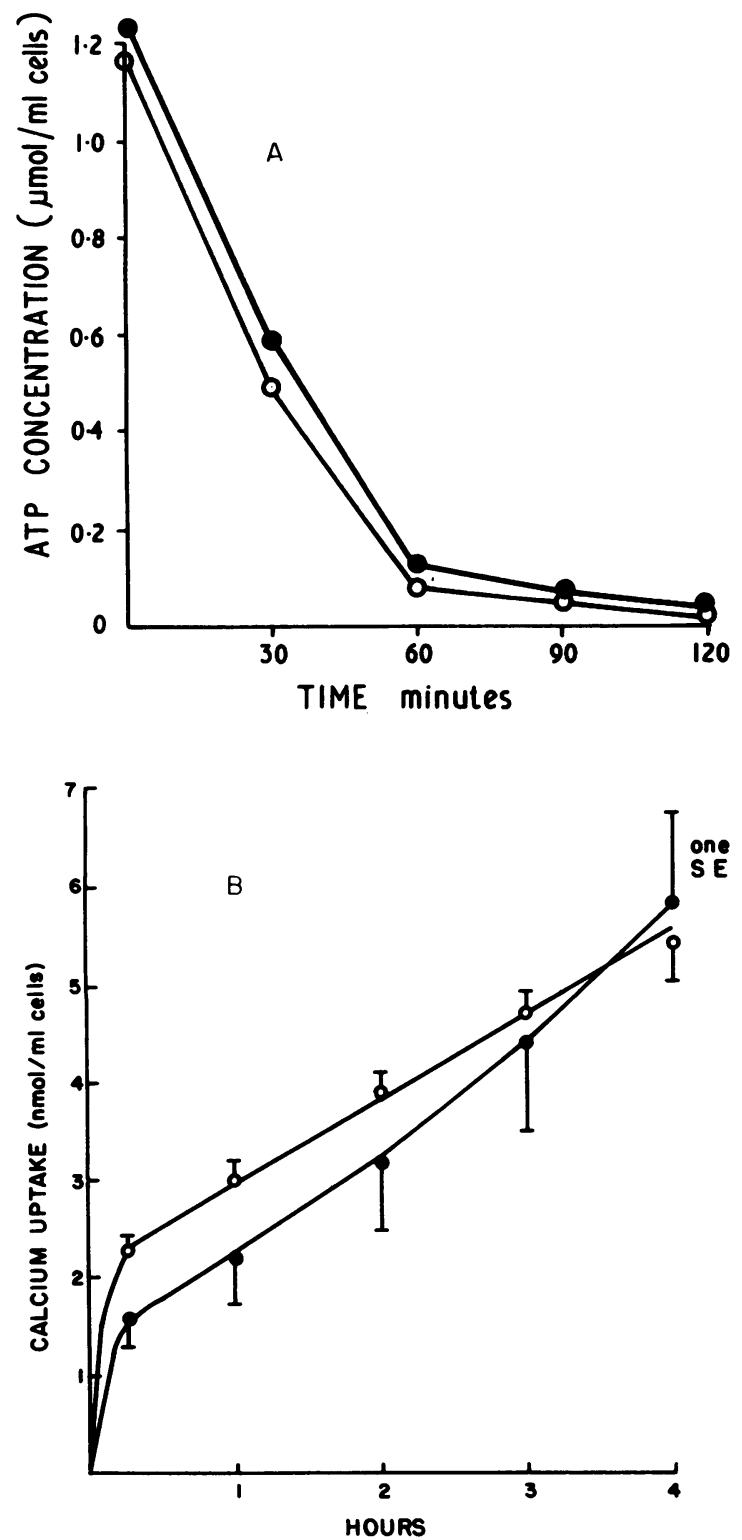

FIGURE 1 (A) ATP concentration of erythrocytes incubated at $37^{\circ} \mathrm{C}$ with $10 \mathrm{mM}$ inosine plus $1 \mathrm{mM}$ iodoacetate $(O)$ or inosine plus $5 \mathrm{mM}$ iodoacetamide (O). (B) Calcium uptake by erythrocytes depleted of ATP by either inosine plus iodoacetate $(O)$ or iodoacetamide $(O)$. Mean values are for 22 or 6 normal donors, respectively, and show \pm 1 SE by the vertical bars.

in direct proportion to the percent reticulocytes present $(r=0.88, P<0.001)$ and the influx was twofold normal for cells with $20 \%$ reticulocytosis. In contrast the $\mathrm{Ca}^{2+}$ uptake was elevated 11-fold normal in cells with $20 \%$ reticulocytosis (Fig. 3). A linear relation existed between $\mathrm{Ca}^{2+}$ uptake and percent reticulocytes $(r=0.71$, $P<0.01$ ) although the regression line did not pass through the mean for normal erythrocytes. Calcium uptake showed no correlation with erythrocyte creatine which was measured in 12 reticulocyte-rich cell suspensions as an index of the mean erythrocyte age. Sodium influx was measured into erythrocytes both before and after depletion of ATP with iodoacetate plus inosine. No increase in $\mathrm{Na}^{+}$influx was found in depleted cells in three separate experiments.

$\left[{ }^{3} \mathrm{H}\right] \mathrm{Ouabain}$ binding to reticulocytes. Reticulocytes bound more ouabain than normal cells and there was a direct relation between the number of ouabain molecules bound per cell and the percentage of reticulocytes present (Fig. 4). Eight patients were studied with reticulocytosis between 4 and 20\%, and the number of binding sites per cell increased about twofold over this range. Seven normal subjects gave a value $362 \pm 69$ for the mean number of ouabainbinding sites per erythrocyte. One subject (C. S.) gave repeated values of $320,326,278,332$, and 322 sites/cell at intervals over $2 \mathrm{yr}$ and other subjects also gave reproducible results.

Potassium influx. The ouabain-sensitive (active) component of $\mathrm{K}^{+}$influx was increased for the eight patients with reticulocytosis $(2.28 \pm 0.83 \mu \mathrm{eq} / \mathrm{ml}$ cells per $h)$ when compared with normals $(1.46 \pm 0.20 \mu \mathrm{eq} /$ $\mathrm{ml}$ cells per $\mathrm{h} ; P<0.01)$. However there was no difference in ouabain-insensitive $\mathrm{K}^{+}$influx between the two groups $(0.47 \pm 0.17 \mu \mathrm{eq} / \mathrm{ml}$ cells per $\mathrm{h}$ for patients and $0.46 \pm 0.10 \mu \mathrm{eq} / \mathrm{ml}$ cells per $\mathrm{h}$ for normals).

\section{DISCUSSION}

The influx of $\mathrm{Ca}^{2+}$ into human erythrocytes can only be adequately studied under conditions which inactivate the outward $\mathrm{Ca}^{2+}$ pumping. Selective inhibition of the pump is difficult to achieve since ruthenium red, $\mathrm{La}^{3+}$ ions, or chlorpromazine ${ }^{2}$ block not only the outward pumping of $\mathrm{Ca}^{2+}$ but also the passive inward movement of this cation. Rapid depletion of ATP however inhibits the $\mathrm{Ca}^{2+}$ pump and allows a measurable uptake of $\mathrm{Ca}^{2+}$ ions (11). Circumstantial evidence suggests that this uptake measures the passive $\mathrm{Ca}^{2+}$ permeability of energy-replete cells. First, cells pretreated with two different metabolic inhibitors (iodoacetate and iodoacetamide) gave the same values for $\mathrm{Ca}^{2+}$ uptake (Figs. 1B and 2) which suggests that $\mathrm{Ca}^{2+}$ entry resulted from ATP depletion and not from a membrane effect of the inhibitor to increase $\mathrm{Ca}^{2+}$ permeability. Second, $\mathrm{Na}^{+}$influx into ATP-depleted cells was about the same as for ATP-rich cells which agrees with a previous study (17) and shows that iodoacetate or iodoacetamide pretreatment does not increase passive permeability to cation. A rapid initial uptake of 1-2 $\mathrm{nmol}{ }^{45} \mathrm{Ca} / \mathrm{ml}$ cells occurs within the first $5 \mathrm{~min}$ of incubation of erythrocytes with isotopic $\mathrm{Ca}^{2+}$. This

\footnotetext{
${ }^{2}$ Wiley, J. S., and C. C. Shaller. Unpublished observations.
} 


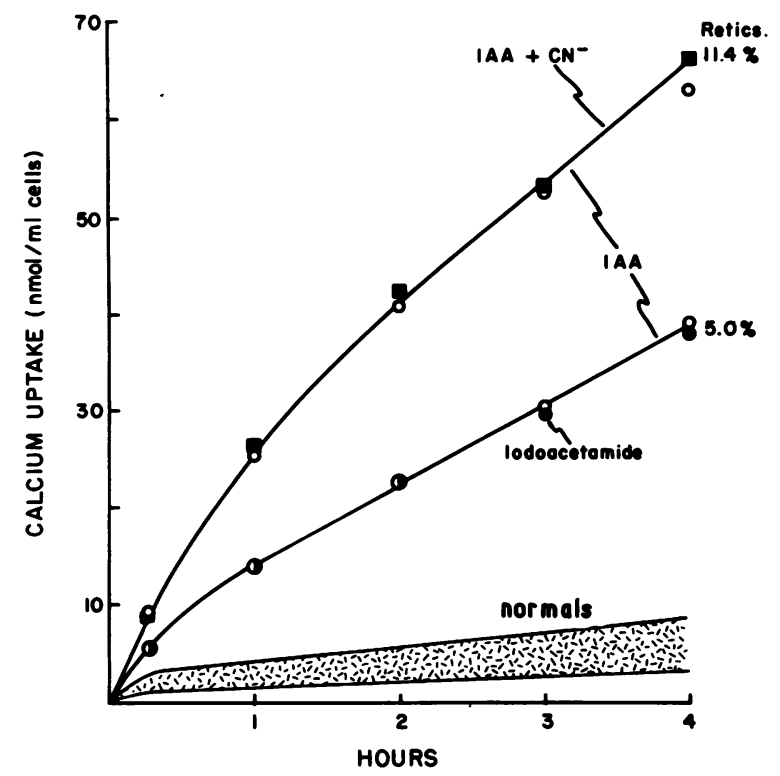

FIGURE 2 Calcium uptake by reticulocyte-rich erythrocytes, with either $11.4 \%$ reticulocytes (Retics.) (upper curve) or $5.0 \%$ reticulocytes (lower curve). Cells were depleted of ATP by preincubation with inosine plus iodoacetate $(O)$, inosine plus iodoacetamide (O), or inosine plus iodoacetate plus cyanide $(\square)$. Uptake for normal erythrocytes $\pm 2 \mathrm{SD}$ is shown by the cross-hatching.

initial uptake is the same for either ATP-rich or ATP-depleted cells and its rate is one to two orders of magnitude faster than the subsequent uptake of $\mathrm{Ca}^{2+}$ by ATP-depleted cells. Such rapid kinetics suggest that the initial uptake is a distinct process from transmembrane $\mathrm{Ca}^{2+}$ movement and may represent an exchange of membrane ${ }^{40} \mathrm{Ca}$ with ${ }^{45} \mathrm{Ca}$ in the medium. The slow uptake of $\mathrm{Ca}^{2+}$ between $15 \mathrm{~min}$ and $4 \mathrm{~h}$ can be shown with either ${ }^{45} \mathrm{Ca}$ or total $\mathrm{Ca}^{2+}$ analysis and measures transmembrane movement. Values for this flux confirm the very low $\mathrm{Ca}^{2+}$ permeability of erythrocytes, shown by Schatzmann and Vincenzi

TABLE II

Calcium Uptake by Reticulocyte-Enriched Normal Erythrocytes

\begin{tabular}{lcc}
\hline Fraction & Reticulocytes & $\mathrm{Ca}^{2+}$ uptake \\
\hline & $\%$ & nmol/ml cells/4 $h$ \\
Top & 2.4 & 22.1 \\
Middle & 0.8 & 9.2 \\
Bottom & 0.3 & 8.5 \\
\hline
\end{tabular}

Washed erythrocytes were fractionated by centrifugation at $28,000 \mathrm{~g}$ for $60 \mathrm{~min}$ at $30^{\circ} \mathrm{C}$. Cell ATP was then depleted by incubation for $90 \mathrm{~min}$ in media containing inosine plus iodoacetic acid. Finally $\mathrm{Ca}^{2+}$ uptake was measured over a 4- $\mathrm{h}$ incubation in saline media containing $1.5 \mathrm{mM}{ }^{45} \mathrm{Ca} \mathrm{Cl}_{2}$.

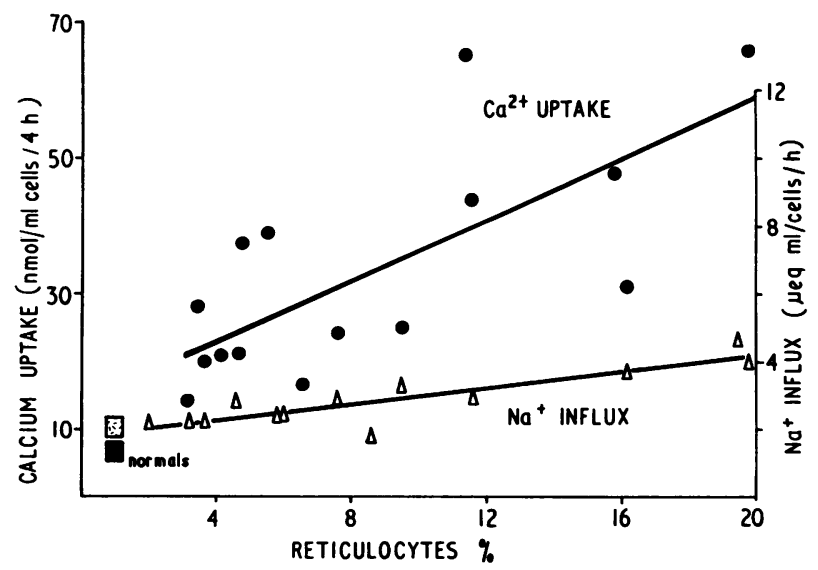

Figure 3 Comparison of $\mathrm{Ca}^{2+}$ uptake with $\mathrm{Na}^{+}$influx in cells with reticulocytosis from 2 to $20 \%$. Regression lines have been fitted by the method of least squares with $r$ $=0.71$ for $\mathrm{Ca}^{2+}$ uptake and $r=0.88$ for $\mathrm{Na}^{+}$influx. Mean for normals $\pm 1 \mathrm{SD}$ are shown for $\mathrm{Na}^{+}$influx (upper rectangle) and $\mathrm{Ca}^{2+}$ uptake (lower rectangle).

(18) for fresh cells stored at $4^{\circ} \mathrm{C}$ in plasma and by others for ATP-depleted cells at $37^{\circ} \mathrm{C}(11,19)$.

The main finding is that reticulocytes have a $\mathrm{Ca}^{2+}$ permeability which is many fold greater than that of mature erythrocytes. Both $\mathrm{Na}^{+}$and $\mathrm{Ca}^{+}$influx were increased in the presence of reticulocytosis but while $\mathrm{Na}^{+}$flux increased 2-fold, the $\mathrm{Ca}^{2+}$ flux increased 11-fold for cells with $20 \%$ reticulocytosis. Extrapolation of these values suggest that reticulocytes have a 6fold greater $\mathrm{Na}^{+}$influx and 43-fold greater $\mathrm{Ca}^{2+}$ uptake than mature cells. Two factors contribute to this difference between reticulocytes and mature cells; first, the permeability to $\mathrm{Ca}^{2+}$ per square micrometer of membrane, and second, the membrane surface area. Although the membrane area cannot be directly measured, a relative estimate has been provided by the

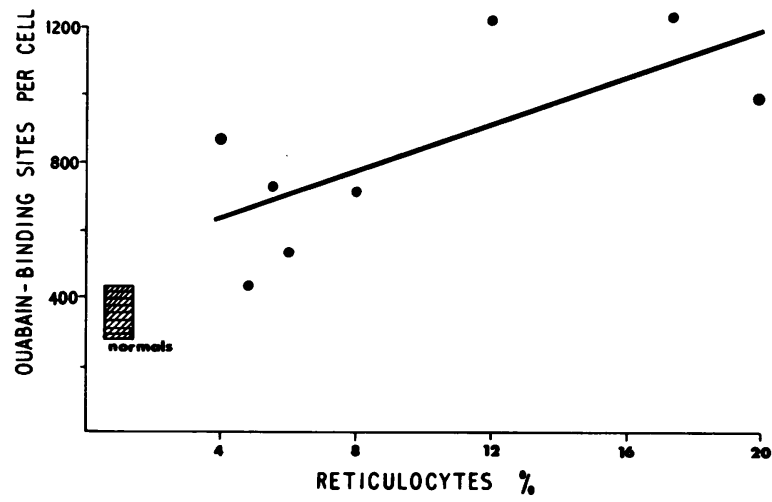

Figure 4 Correlation between ouabain binding sites per cell and percent reticulocytes in the suspension. Regression line has been fitted by the method of least squares with $r=0.70$. Mean for normals $\pm 1 \mathrm{SD}$ is shown in the shaded rectangle. 
lipid analyses of Shattil and Cooper (3). Cell membranes of reticulocytes lose $35 \%$ of their cholesterol and phospholipid on maturation which probably accompanies a decrease in membrane surface area of similar magnitude. Reticulocyte volume also decreases about $25-30 \%$ on maturation so that the membrane area of reticulocytes may be approximately $10 \%$ greater than that of mature cells when compared on a unit volume basis. Although this estimate is only approximate it does show that the many-fold reduction in cation fluxes on maturation of the reticulocyte can be attributed largely to a decrease in membrane permeability. The ratio of $\mathrm{Ca}^{2+}: \mathrm{Na}^{+}$fluxes is quite independent of relative membrane area. The $\mathrm{Ca}^{2+}: \mathrm{Na}^{+}$ flux ratio falls by a factor of about 7 as the reticulocyte changes to an erythrocyte so that maturation of the reticulocyte leads to a selective loss of $\mathrm{Ca}^{2+}$ permeability.

Several lines of evidence suggest that reticulocytes lose their high $\mathrm{Ca}^{2+}$ permeability on maturation rather than during erythrocyte aging. First, the $\mathrm{Ca}^{2+}$ influx correlates well with percentage of reticulocytes (Fig. 3) but this flux does not correlate with erythrocyte creatine which reflects the mean cell age $(13,20)$. Second, when erythrocytes are separated by centrifugation into fractions of varying ages, the fraction with old cells showed the same $\mathrm{Ca}^{2+}$ uptake as the bulk of the red cell population. The mechanism by which $\mathrm{Ca}^{2+}$ permeability is selectively lost is not known although it may relate to the disappearance of membrane proteins specific to the reticulocyte (21). Absolute values for the $\mathrm{Ca}^{2+}$ influx may be calculated from the $\mathrm{Ca}^{2+}$ uptake of ATP-depleted erythrocytes $(5.4 \mathrm{nmol} / \mathrm{ml}$ cells per $4 \mathrm{~h}$ ) assuming a surface area of $134 \mu \mathrm{m}^{2}$ and mean cell volume of $85 \mathrm{Al}(22)$. For mature cells the flux is $2 \times 10^{-5} \mathrm{pmol} / \mathrm{cm}^{2}$ per s and for reticulocytes about $1 \times 10^{-3} \mathrm{pmol} / \mathrm{cm}^{2}$ per $\mathrm{s}$, although the latter value is approximate and depends on the assumption that reticulocytes and mature cells have the same membrane area per unit volume. This assumption is only approximate since reticulocytes are more osmotically resistant than mature cells which indicates a slightly greater surface area-to-volume ratio of these more immature cells (3). Whatever the exact values, it is clear that erythrocyte $\mathrm{Ca}^{2+}$ permeability is many orders of magnitude less than for squid axon, $\mathrm{HeLa}$ cells, or ascites tumor cells where flux values about $0.1 \mathrm{pmol} / \mathrm{cm}^{2}$ per $\mathrm{s}$ have been found (23-25).

The concept of a "normal" cell $\mathrm{Ca}^{2+}$ concentration is imprecise since cell $\mathrm{Ca}^{2+}$ depends upon several factors such as ambient $\mathrm{Ca}^{2+}$ levels and the number of saline washes before dry ashing of erythrocytes. Previous studies have reported mean values for erythrocyte $\mathrm{Ca}^{2+}$ of 16 and $15 \mathrm{nmol} / \mathrm{ml}$ cells $(26,27)$. A wide range of individual values from 5 to $22 \mathrm{nmol} / \mathrm{ml}$ cells was observed by Harrison and Long (26) who found that inclusion of EDTA in the washing medium reduced mean erythrocyte $\mathrm{Ca}^{2+}$ to only $2 \mathrm{nmol} / \mathrm{ml}$ cells. The present results gave a mean erythrocyte $\mathrm{Ca}^{2+}$ of $5.9 \pm 1.8 \mathrm{nmol} / \mathrm{ml}$ cells whether EGTA was present in the $\mathrm{Ca}^{2+}$-free washing medium or not. The discrepancies between these studies may in part relate to the small $\mathrm{Ca}^{2+}$ contamination (about 1-2 $\mu \mathrm{M})$ always present in saline washing media of previous studies. This $\mathrm{Ca}^{2+}$ may associate with phosphate anions leaking from the cells during washing so that insoluble calcium phosphate forms on the cell surface and is included in the cell $\mathrm{Ca}^{2+}$ analysis. Whatever value is accepted for erythrocyte $\mathrm{Ca}^{2+}$, the analyses in this study employed consistent methods so it is valid to conclude that reticulocyte-rich (525\%) erythrocytes have the same total cell $\mathrm{Ca}^{2+}$ concentration as mature cells. However, $\mathrm{Ca}^{2+}$ of reticulocytes can exchange more completely with isotopic ${ }^{45} \mathrm{Ca}^{2+}$ in the external medium, presumably because of the greater $\mathrm{Ca}^{2+}$ permeability of reticulocyte membranes.

Reticulocytes possess an increased number of cation pump sites which have been quantitated in this study by the $\left[{ }^{3} \mathrm{H}\right]$ ouabain binding technique. Pump sites were increased about three-fold in cells with $20 \%$ reticulocytosis which extrapolates to a value of about 4,000 sites for each reticulocyte. This value is 11fold higher than the pump site numbers found for mature erythrocytes of $362 \pm 69$ sites/cell. Estimates for the ouabain-binding sites in mature human erythrocytes range between 228 and 1,200 sites/cells (28, 29), with most studies finding between 250 and 500 sites/cell (30-32). Active $\mathrm{K}^{+}$influx into reticulocyterich cells is also increased above normal although the stimulation of flux is less than expected from the increment in pump sites. This may be explained by the low normal or subnormal concentrations of $\mathrm{Na}^{+}$ in the reticulocyte (6).

Control of cytoplasmic $\mathrm{Ca}^{2+}$ concentration is an important function of all cell types. Low cytoplasmic $\mathrm{Ca}^{2+}$ concentrations may be achieved by accumulation of this cation within organelles such as the sarcoplasmic reticulum of muscle, the dense granules of blood platelets, or mitochondria of various cells. The human erythrocyte lacks organelles and the low $\mathrm{Ca}^{2+}$ content of this cell is maintained by a calcium pump which extrudes this ion from the cytoplasm to the cell exterior (18). This calcium pump is an ATPase, which is active at the micromolar $\mathrm{Ca}^{2+}$ concentrations normally present in human erythrocytes $(33,34)$. Energy requirements by this calcium pump normally are only a negligible fraction of ATP production from glycolysis. The 43-fold decrease in $\mathrm{Ca}^{2+}$ permeability which occurs on maturation of the reticulocyte thus effectively limits the energy needed by the mature cell for $\mathrm{Ca}^{2+}$ homeostasis. Any failure by the mature cell to acquire 
this low $\mathrm{Ca}^{2+}$ permeability will lead to cell destruction, which is well illustrated by the association of hemolytic anemia with a congenital erythrocyte $\mathrm{Ca}^{2+}$ leak (35).

\section{ACKNOWLEDGMENTS}

We thank Dr. Richard A. Cooper for helpful discussions and Dr. Toshio Asakura for measurements of ATP.

This work was supported by grant HL 16201 from the National Institutes of Health.

\section{REFERENCES}

1. Stryckmans, P. A., E. P. Cronkite, G. Giacomelli, L. M. Schiffer, and H. Schnappauf. 1968. The maturation and fate of reticulocytes after in vitro labeling with tritiated amino acids. Blood. 31: 33-43.

2. Ganzoni, A., R. S. Hillman, and C. A. Finch. 1969. Maturation of the macroreticulocyte. Br.J. Haematol. 16: $119-135$.

3. Shattil, S. J., and R. A. Cooper. 1972. Maturation of macroreticulocyte membranes in vivo. J. Lab. Clin. Med. 79: 215-227.

4. Come, S. E., S. B. Shohet, and S. H. Robinson. 1974. Surface remodeling vs. whole-cell hemolysis of reticulocytes produced with erythroid stimulation or irondeficiency anemia. Blood. 44: 817-1830.

5. Wise, W. C. 1976. Maturation of membrane function: transport of amino acid by rat erythroid cells. J. Cell. Physiol. 87: 199-211.

6. Bernstein, R. E. 1959. Alterations in metabolic energetics and cation transport during aging of red cells. J. Clin. Invest. 38: 1572-1586.

7. Lauf, P. K., B. A. Rasmusen, P. G. Hoffman, P. B. Dunham, P. Cook, M. L. Parmelee, and D. C. Tosteson. 1970. Stimulation of active potassium transport in LK sheep red cells by blood group-L-antiserum. J. Membr. Biol. 3: 1-13.

8. Smith, E. K. M., and L. G. Welt. 1967. A reversible defect of membrane ATPase in the red cells of uremic patients. Clin. Res. 15: 51. (Abstr.)

9. Cooper, R. A., and J. H. Jandl. 1968. Bile salts and cholesterol in the pathogenesis of target cells in obstructive jaundice. J. Clin. Invest. 47: 809-822.

10. Dacie, J. V., and S. M. Lewis. 1975. Practical Haematology. J. \& A. Churchill Ltd., London. 5th edition. 79.

11. Lew, V. L. 1971. On the ATP dependence of the $\mathrm{Ca}^{2+}$ induced increase in $\mathrm{K}^{+}$permeability observed in human red cells. Biochim. Biophys. Acta. 233: 827-830.

12. Wiley, J. S., and R. A. Cooper. 1974. A furosemidesensitive cotransport of sodium plus potassium in the human red cell. J. Clin. Invest. 53: 745-755.

13. Griffiths, W. J., and M. Fitzpatrick. 1967. The effect of age on the creatine in red cells. Br. J. Haematol. 13: $175-180$.

14. Hoffman, J. F. 1969. The interaction between tritiated ouabain and the Na-K pump in red blood cells. J. Gen. Physiol. 54: 343s-350s.

15. Wiley, J. S., J. C. Ellory, M. A. Shuman, C. C. Shaller, and R. A. Cooper. 1975. Characteristics of the membrane defect in the hereditary stomatocytosis syndrome. Blood. 46: $337-356$.
16. Murphi, J. R. 1973. Influence of temperature and method of centrifugation on the separation of erythrocytes. J. Lab. Clin. Med. 82: 334-341.

17. Hoffman, J. F., and F. M. Kregenow. 1966. The characterization of new energy dependent cation transport processes in red blood cells. Ann. N. Y. Acad. Sci. 137: 566-576.

18. Schatzmann, H. J., and F. F. Vincenzi. 1969. Calcium movements acoss the membrane of human red cells. J. Physiol. (Lond.). 201: 369-395.

19. Kregenow, F. M., and J. F. Hoffman. 1972. Some kinetic and metabolic characteristics of calcium-induced transport in human red cells. J. Gen. Physiol. 60: 406-429.

20. Griffiths, W. J., and E. J. Lothian. 1969. Erythropoiesis, red-cell creatine and plasma aldolase activity in anaemia in the rabbit and man. Br. J. Haematol. 17: 477-484.

21. Koch, P. A., F. H. Gardner, and J. R. Carter, Jr. 1973. Rec cell maturation: loss of a reticulocyte-specific membrane protein. Biochem. Biophys. Res. Commun. 54: $1296-1299$.

22. Canham, P. B., and A. C. Burton. 1968. Distribution of size and shape in populations of normal human red cells. Circ. Res. 22: 405-422.

23. Blaustein, M. P., and A. L. Hodgkin. 1969. The effect of cyanide on the efflux of calcium from squid axons. J. Physiol. (Lond.). 200: 497-527.

24. Borle, A. B. 1969. Kinetic analysis of calcium movements in Hela cell cultures. I. Calcium influx. J. Gen. Physiol. 53: 43-56.

25. Cittadini, A., A. Scarpa, and B. Chance. 1973. Calcium transport in intact Ehrlich Ascites tumor cells. Biochim. Biophys. Acta. 291: 246-259.

26. Harrison, D. G., and C. Long. 1968. The calcium content of human erythrocytes. J. Physiol. (Lond.). 199: 367-381.

27. Lichtman, M. A., and R. I. Weed. 1972. Divalent cation content of normal and ATP-depleted erythrocytes and erythrocyte membranes. Nouv. Rev. Fr. Hematol. 12: 799-813.

28. Erdmann, E., and W. Hasse. 1975. Quantitative aspects of ouabain binding to human erythrocyte and cardiac membranes. J. Physiol. (Lond.). 251: 671-682.

29. Gardner, J. D., and T. P. Conlon. 1972. The effects of sodium and potassium on ouabain binding by human erythrocytes. J. Gen. Physiol. 60: 609-629.

30. Ellory, J. C., and R. D. Keynes. 1969. Binding of tritiated digoxin to human red cell ghosts. Nature (Lond.). 221: 776.

31. Hoffman, J. F. 1973. Molecular aspects of the $\mathrm{Na}^{+}$, $\mathrm{K}^{+}$-pump in red blood cells. In Organization of EnergyTransducing Membranes. M. Nakao and L. Packer, editors. University Park Press, Baltimore. 9-21.

32. Lauf, P. K., and C. H. Joiner. 1976. Increased potassium transport and ouabain binding in human $\mathrm{Rh}^{\text {null }}$ red blood cells. Blood. 48: 457-468.

33. Ferreira, H. G., and V. L. Lew. 1976. Use of ionophore A23187 to measure cytoplasmic Ca buffering and activation of the Ca pump by intermal Ca. Nature (Lond.). 259: 47-49.

34. Schatzmann, H. J. 1973. Dependence on calcium concentration and stoichiometry of the calcium pump in human red cells. J. Physiol. (Lond.). 235: 551-569.

35. Wiley, J. S., and F. M. Gill. 1976. Red cell calcium leak in congenital hemolytic anemia with extreme microcytosis. Blood. 47: 197-210. 